\title{
Parasitic infections in ornamental cichlid fish in the Peruvian Amazon
}

\author{
Infestação parasitária em ciclídeos ornamentais da Amazônia de Peru \\ Jefferson Yunis Aguinaga ${ }^{1}$; Paulo Fernandes Marcusso ${ }^{2}$; Gustavo da Silva Claudiano ${ }^{2}$; Bruno Tadeu Marotta Lima ${ }^{1}$; \\ Fernanda de Alexandre Sebastião ${ }^{3}$; João Batista Kochenborger Fernandes ${ }^{1}$; \\ Flávio Ruas de Moraes ${ }^{2}$; Julieta Rodini Engracia de Moraes ${ }^{1,2 *}$ \\ ${ }^{1}$ Aquaculture Center, Universidade Estadual Paulista - UNESP, Jaboticabal, SP, Brazil \\ ${ }^{2}$ Department of Animal Pathology, College of Agricultural Sciences and Veterinary, Universidade Estadual Paulista - UNESP, \\ Jaboticabal, SP, Brazil \\ ${ }^{3}$ Department of Microbiology, College of Agricultural Sciences and Veterinary, Universidade Estadual Paulista - UNESP, Jaboticabal, \\ SP, Brazil
}

Received July 22, 2014

Accepted September 1, 2014

\begin{abstract}
The aim of this study was to evaluate the prevalence and seasonal distribution of the main parasite species in Amazonian ornamental cichlids that affect their trade. The study was conducted from August 2007 to September 2009. We sampled 3042 specimens from 9 different species, of which $9.47 \%$ had at least one type of external parasite. $81.25 \%$ of the cases occurred in the dry season. Crenicichla anthurus $(28.57 \%)$ was the most parasitized, followed by Aequidens diadema (26.32\%), Pterophyllum scalare (22.69\%), Cichlasoma sp. (9.52\%), Apistogramma sp. (3.88\%) and Symphysodon aequifasciatus (3.66\%). Monogenea was the most abundant group of parasites, occurring in $66.67 \%$ of the cases, of which $96.88 \%$ occurred in the dry season. This parasite infested $95.68 \%$ of Pterophyllum scalare, $76.67 \%$ of Apistogramma sp, $33.33 \%$ of Cichlasoma sp. and $23.81 \%$ of Symphysodon aequifasciatus cases. Ichthyophthirius multifiliis infested 100\% of Aequidens diadema, 76.19\% of Symphysodon aequifasciatus, $66.67 \%$ of Cichlasoma sp, 41.67\% of Crenicichla anthurus and 23.33\% of Apistogramma sp cases. Myxosporidia infested 58.33\% of Crenicichla anthurus. Trichodina infested $4.32 \%$ of Pterophyllum scalare. The prevalence of these parasites is related to the season, preferred habitat, fish behavior, individual susceptibility and handling of animals during transportation by fishermen.
\end{abstract}

Keywords: Ornamental fish, Cichlid, parasites, Amazon.

\section{Resumo}

O objetivo deste estudo foi avaliar a prevalência e distribuição sazonal das principais espécies de parasitas em ciclídeos ornamentais amazônicos que afetam seu comércio. O estudo foi realizado entre agosto de 2007 e setembro de 2009. Foram amostrados 3042 espécimes de 9 espécies diferentes, das quais 9,47\% tinham pelo menos um tipo de parasita externo. Na estação seca, ocorreram $81,25 \%$ dos casos. Crenicichla anthurus $(28,57 \%)$ foi o mais parasitado, seguido por Aequidens diadema (26,32\%), Pterophyllum scalare (22,69\%), Cichlasoma sp. (9,52\%), Apistogramma sp. (3,88\%), e Symphysodon aequifasciatus (3,66\%). Monogenea foi o grupo mais abundante de parasitas, ocorrendo em 66,67\% dos casos. Na estação seca, ocorreram 96,88\% deles. Este parasita infestou 95,68\% dos casos em Pterophyllum scalare, 76,67\% em Apistogramma sp., 33,33\% em Cichlasoma sp. e 23,81\% em Symphysodon aequifasciatus. Ichthyophthirius multifiliis infestou 100\% dos casos em Aequidens diadema, 76,19\% em Symphysodon aequifasciatus, 66,67\% em Cichlasoma sp., 41,67\% em Crenicichla anthurus e 23,33\% em Apistogramma sp.; Myxosporidia infestou 58,33\% dos casos em Crenicichla anthurus; Trichodina infestou 4,32\% dos casos em Pterophyllum scalare. A prevalência desses parasitas está relacionada com a época do ano, hábitat preferido, comportamento dos peixes, suscetibilidade individual e manejo dos animais durante o transporte pelos pescadores.

Palavras-chave: Peixes ornamentais, Cichlidae, parasitas, Amazônia.

*Corresponding author: Julieta Rodini Engracia de Moraes, Aquaculture

Center, Universidade Estadual Paulista - UNESP, Via Pr. Paul Donato

Castellane, km 05, CEP: 14884-900, Jaboticabal, SP, Brazil,

e-mail: julietaengracia@gmail.com 


\section{Introduction}

The ornamental fish trade is one of the most important economic activities for thousands of poor people in the Amazon region. In Peru, this activity generates around US\$3.5 million/year, exporting about 6.7 million fish (MOREAU \& COOMES, 2007). Nearly all Amazon fish exported from the natural environment are obtained by local fishermen, who transfer the fish to agents who, later on, transfer them to exporters so as to reach aquarium stores worldwide. It has been estimated that in this transport chain, 73\% of the fish die, due to several causes (OLIVIER, 2001).

Parasites are abundant in tropical climates, and are one of the major causes of death and disposal of ornamental fish, thus representing large economic losses. Because of the small size of these fish, they are easily affected by small numbers of parasites. These infestations are favored by the ease of access and penetration that are provided by aquatic environments, transport stress and improper handling, and are related to the wide variety of species involved and the few studies that have been conducted on them (TAKEMOTO et al., 2004).

The host-parasite relationship is strongly influenced by the environment. The Amazon region possesses marked seasonality: a rainy season between November and April and a dry season from May to October (FIGUEROA \& NOBRE, 1989). At this latitude, there is little variation in temperature and light intensity. On the other hand, there is a negative relationship between precipitation and turbidity (SILVA et al., 2008), which may influence the infestation by parasites.

The most common ornamental fish parasites are Monogenea (platyhelminths), as reported by Fujimoto et al. (2013) in Moenkhausia sanctaefilomenae and Astyanax bimaculatus. Other important parasites are protozoa of the phylum Ciliophora, for example Ichthyophthirius multifliis and Trichodina sp, previously reported by Thilakaratne et al. (2003) in Pterophyllum scalare and Kim et al. (2002) in Puntius tetrazona. Schalch and Moraes (2005) reported myxosporidian parasites in Leporinus macrocephalus.

Cichlids are one of the major ornamental fish families, due to the large number of species and the demand for these fish for ornamental purposes. This demand is explained by the variety of shapes, extravagant colors and special behavior of the different species that are included in this family (KULLANDER \& SILFVERGRIP, 1991).

The aim of this study was to identify external parasites of economic importance in ornamental cichlids, as well as the seasonal behavior of these parasites in the Peruvian Amazon.

\section{Materials and methods}

From August 2007 to September 2009, we collected fish weekly from the rivers Huallaga, Napo, Tigre, Amazonas, Corrientes, Pastaza, Nanay and Ucayali, which are located in the Peruvian Amazon region. These fish were obtained from artisanal fishermen before being sold to exporters.

3042 specimens of ornamental fish belonging to the species Crenicichla anthurus (42), Aequidens diadema (114), Pterophyllum scalare (714), Cichlasoma sp. (126), Apistogramma sp (774), Symphysodon aequifasciatus (1146), Heros efasciatus (49), Laetacara thayeri (54) and Acarichthys heckelli (23) were examined macroscopically and microscopically for the presence of ectoparasites.

The fish were sampled randomly and sacrificed with benzocaine solution $(1: 10000)$ diluted in ethanol $98^{\circ}(0.1 \mathrm{~g} / \mathrm{mL})$ (WEDEMEYER, 1970) for parasitological examination of skin smears. The mucus obtained was placed on a slide with a drop of $0.85 \%$ saline solution, and then compressed with a cover slip for microscopic examination. Gill arches were removed and placed in a Petri dish with $0.85 \%$ saline solution for stereoscope visualization. Parasite identification followed the recommendations of Travassos et al. (1928) and Thatcher (1991).

Prevalence rates were calculated for each genus recovered, by means of the equation $\mathrm{P}=$ number of infected fish / total number of fish examined $x 100$. We used the chi-square test to compare prevalences using the SAS 9.1 computer software.

\section{Results and Discussion}

Among the 3042 ornamental cichlid specimens, 9.47\% were parasitized (Table 1): two species of ciliates (Ichthyophthirius multifiliis, Trichodina sp.), one of Monogenea (Dactylogyrus sp.), and one of Myxosporea (Table 2). Three fish species were infected by two species of parasites (Table 2). Table 3 specifies the places from which the parasites was identified. Other authors have reported higher prevalence of parasites, such as Thilakaratne et al. (2003) who reported $45.3 \%$ and Piazza et al. (2006) who observed 34\%. However, these authors worked with other fish species and in different regions. Another fact which should be noted is that in the present study, the assessments were performed at the beginning of the commercial chain, shortly after capture, while the above authors made their observations at the end of the process, at a time when, according to Olivier (2001), the cumulative mortality reaches $73 \%$.

Monogenea presented the highest prevalence in most of the fish species followed by the protozoon I. multifiliis. Similarly, Tavares-Dias et al. (2010) reported Monogenea and I. multifiliis as

Table 1. Hosts examined from August 2007 to September 2009 in the Amazon of Peru.

\begin{tabular}{lccc}
\hline \multirow{2}{*}{\multicolumn{1}{c}{ Species }} & \multicolumn{3}{c}{ Parasitized } \\
\cline { 2 - 4 } & Examined fish & N & \% \\
\hline Crenicichla anthurus & 42 & 12 & 28.57 \\
Aequidens diadema & 114 & 30 & 26.32 \\
Pterophyllum scalare & 714 & 162 & 22.69 \\
Cichlasoma sp. & 126 & 12 & 9.52 \\
Apistogramma sp. & 774 & 30 & 3.88 \\
Symphysodon aequifasciatus & 1146 & 42 & 3.66 \\
Heros efasciatus & 49 & 0 & 0.00 \\
Laetacara thayeri & 54 & 0 & 0.00 \\
Acarichthys heckelli & 23 & 0 & 0.00 \\
& & & \\
TOTAL & 3042 & 288 & 9.47 \\
\hline
\end{tabular}

(N) Parasitized fish; (\%) Prevalence. 
Table 2. Frequency of parasites in ornamental cichlids collected from rivers in the Peruvian Amazon in two different seasons.

\begin{tabular}{|c|c|c|c|c|c|c|}
\hline \multirow{2}{*}{ Species } & \multicolumn{3}{|c|}{ Rainy season } & \multicolumn{3}{|c|}{ Dry season } \\
\hline & Ich & Mon & Myx & Ich & Mon & Tri \\
\hline A. heckelli & 0 & 0 & 0 & 0 & 0 & 0 \\
\hline A. diadema & 19 & 0 & 0 & 11 & 0 & 0 \\
\hline Apistogramma sp. & 0 & 0 & 0 & 7 & 23 & 0 \\
\hline Cichlasoma sp. & 8 & 0 & 0 & 0 & 4 & 0 \\
\hline C. anthurus & 0 & 0 & 7 & 5 & 0 & 0 \\
\hline H. efasciatus & 0 & 0 & 0 & 0 & 0 & 0 \\
\hline L. thayeri & 0 & 0 & 0 & 0 & 0 & 0 \\
\hline P. scalare & 0 & 6 & 0 & 0 & 149 & 7 \\
\hline S.aequifasciatus & 14 & 0 & 0 & 18 & 10 & 0 \\
\hline
\end{tabular}

Ich: Ichthyophthirius multifiliis; Mon: Monogenea; Myx: Myxosporidia; Tri: Trichodina sp.

Table 3. Percentage of parasites infestation in ornamental cichlids by the site where they were collected from Peruvian Amazon region.

\begin{tabular}{lccc}
\hline & Only gills & Only tegument & $\begin{array}{c}\text { Gills + } \\
\text { tegument }\end{array}$ \\
\hline Only Ich & $5.26 \%$ & $73.68 \%$ & $21.05 \%$ \\
Only Mon & $100 \%$ & - & - \\
Only Myx & - & $71.43 \%$ & $28.57 \%$ \\
Only Tri & - & - & $100 \%$ \\
Ich + Mon & $32.76 \%$ & - & $67.24 \%$ \\
Tri + Mon & $33.33 \%$ & - & $66.67 \%$ \\
\hline
\end{tabular}

Ich: Ichthyophthirius multifiliis; Mon: Monogenea; Myx: Myxosporidia; Tri: Trichodina sp.

the most common parasites in the Brazilian Amazon region, while Piazza et al. (2006) and Tavares-Dias et al. (2001) made similar observations in southern Brazil. However, Crenicichla anthurus showed the highest values for parasite prevalence (28.57\%): mainly myxosporidian infection in the rainy season and I. multifliis in the dry season (Table 2). These findings may be related to the preferred habitat of this fish, mainly in the deepest part of the river, which is a place with stagnant water, low oxygen levels and large amounts of decomposing organic material, thus facilitating the parasite cycle (MACMILLAN, 1991).

It is likely that the reproductive period can influence the proliferation of Myxosporidia in the rainy season, due to the stress caused by this activity and the aggressive behavior of this species during that particular period. This was the first study concerning parasites in this fish and the first report of myxosporidian parasites in freshwater fish in Peru. However, there have been reports of this parasite in phylogenetically distant fish in the Amazon basin (FERRAZ, 1999).

Ichthyophthirius multifliis is a cosmopolitan and nonspecific freshwater parasite of fish relating to low temperature and poor water quality (LOM \& DYKOVA, 1992). Aequidens diadema was the fish that was most parasitized by this protozoan in both seasons (Table 2). In the same way as for $C$. anthurus, it is likely that the preferred habitat is related to higher prevalence (KULLANDER, 1986) (Table 4). Higher prevalence occurred in the rainy season $(\mathrm{p}<0.01)$, probably due to stress caused by displacement of these fish to flooded areas, where the oxygen levels and $\mathrm{pH}$ are lower.
Angelfish were parasitized by Monogenea during both seasons, with higher prevalence in the dry season $(\mathrm{p}<0.01)$ (Table 2$)$. This seasonality may be related to water turbidity, which is more manifest in the dry season in the Amazon region (SILVA et al., 2008). The increased amounts of suspended material in the water promotes irritation of gill filaments, thereby increasing the susceptibility to Monogenea (SKINNER, 1982). We also found Trichodina infection in this season, and this reinforces the hypothesis that poor water quality is associated with high turbidity.

We also observed that the high parasite prevalence in this species could be associated with the manner of fish transportation. Fishermen stockpile large quantities of this fish in small spaces, because of the low sale value and abundance of this fish. Another fact that must be considered is their susceptibility to stress, which relates to the social hierarchy of this species and inadequate handling (GÓMEZ-LAPLAZA \& MORGAN, 2003). This situation is accompanied by increased cortisol levels, which have immunosuppressive action. High levels of glucocorticoids for extended times affect the inflammatory response by inhibiting the production of nitric oxide and circulating leukocytes, thus making fish more susceptible to diseases (FAST et al., 2008).

Cichlasoma sp. showed greater prevalence of I. multifiliis in the rainy season and Monogenea in the dry season. The lower prevalence $(9.52 \%)$, in comparison with previous cases $(\mathrm{p}<$ 0.01 ) was probably influenced by the preferred habitat of this species (KULLANDER, 1986) (Table 4). This fish searches for food throughout the water column and has less contact with poor quality water than the other species. Another factor to consider is the large size of this fish, reaching $30 \mathrm{~cm}$ (KULLANDER, 1986): for this reason, fishermen cannot store large quantities of this fish during transportation and therefore the water quality is not drastically compromised. It is noteworthy that this species is usually traded as adults, at an age when they are less susceptible to external parasites (SASAL, 2003).

Dwarf cichlids had low infestation with $I$. multifliis and Monogenea only in the dry season. Although these fish usually live in tree trunks and branches in stagnant water, they showed low prevalence of parasites (3.88\%). Unlike other members of the Cichlidae family, these fish are quite peaceful (KULLANDER, 1986; GOLDSTEIN, 1973), and fights between them are unusual. 
Table 4. List of host fish species and its preferred habitat.

\begin{tabular}{lcc}
\hline \multicolumn{1}{c}{ Species } & Common name & Preferred habitat \\
\hline Acarichthys heckelii (Muller \&Troschel, 1849) & Threadfinned acara & Water column. \\
Aequidens diadema (Heckel, 1840) & Mochoroca & Botton. \\
Apistogramma sp. (Steindachner, 1875) & Dwarf cichlids & Trunk and branches. \\
Cichlasoma sp. (Linnaeus, 1758) & Black acara & Water column. \\
Crenicichla anthurus (Cope, 1872) & Mataguaro & Botton. \\
Heros efasciatus (Heckel, 1840) & Common severum & Water column. \\
Laetacara thayeri (Steindachner, 1875) & Thayeri cichlid & Water column. \\
Symphysodon aequifasciatus (Pellegrin, 1904) & Angelfish & Stagnant water. \\
\hline
\end{tabular}

Therefore, there is less risk of compromising the integrity of the skin and causing subsequent entry of pathogens.

The discus fish is a special case in this group, given that it has a high market value. Fishermen are generally accustomed to practicing more cautious management for this species, such as maintaining low density of fish, changing the water frequently and even providing artificial oxygenation. With all this care, it is not surprising that the prevalence of parasites is low $(3.66 \%)$ (Table 1). However, Chippari-Gomes et al. (2005) reported that this fish is less resistant to stressful conditions and pathogens than other members of the family.

The species Acarichthys heckelli, Heros efasciatus and Laetacara thayeri are larger than the fish described above and are usually aggressive towards other fish of the same species (KULLANDER, 1986; GOLDSTEIN, 1973). For these reasons, these fish are often transported individually, which reduces stress and maintains the water quality for longer. This handling seems to have influenced the non-occurrence of external parasites in these species. Furthermore, fish age may influence the presence of external parasites. In most cases, young fish have more parasites than adults (GRUTTER et al., 2002; SASAL, 2003). Another fact to consider is the preferred habitat; these fish tend to live in the water column where they find their food (KULLANDER, 1986).

The lack of biological and immunological studies on the species discussed here makes it impossible to conclude that some of these fish present natural resistance to external parasites (TAVARESDIAS et al., 2010). In all cases, the fish presented low parasite loads, probably due to the short time between being caught and sold at the port (maximum of three days).

The absence of other external parasites commonly found in tropical fish, such as Dolops, Argulus and Lernaea (SCHALCH \& MORAES, 2005), may be related to the small size of these fish, which are greatly affected by these macroscopic parasites (THILAKARATNE et al., 2003) and become easy prey for predators, or are discarded by fishermen during transportation.

There are deep interactions between parasites, hosts and environments. However, there is lack of information about these interactions in Neotropical ornamental cichlids. In the present study, we observed a relationship between prevalence and preferred habitat. Fish that spend most of their time at the bottom of the water or in standing water showed higher parasite rates than did fish that live in the water column. We also observed a relationship between water turbidity and increased quantities of monogenean parasites, probably due to irritation of the lamellae caused by the suspended matter in the water. Likewise, aggressive fish presented higher rates of parasitism than did non-aggressive fish, possibly due to the injuries from fights and the stress produced by this behavior, which is mainly reported during the reproductive period. It is also noteworthy that there is no information concerning the specific resistance of some of these species, due to the lack of studies on these fish. Finally, there is a factor that is rarely discussed in this type of work but appears to be of great importance: the different handling of each species of fish by fishermen, which is related to the aggressiveness of each species and fish value. The way in which fish are handled certainly influences the prevalence of external parasites in them.

\section{References}

Chippari-Gomes AR, Gomes LC, Lopes NP, Val AL, Almeida-Val VM. Metabolic adjustments in two Amazonian cichlids exposed to hypoxia and anoxia. Comp Biochem Physiol B Biochem Mol Biol 2005; 141(3):347355. http://dx.doi.org/10.1016/j.cbpc.2005.04.006. PMid:15950510

Fast MD, Hosoya S, Johnson SC, Afonso LO. Cortisol response and immune-related effects of Atlantic salmon (Salmo salar Linnaeus) subjected to short- and long-term stress. Fish Shellfish Immunol 2008; 24(2): 194-204. http://dx.doi.org/10.1016/j.fsi.2007.10.009. PMid:18065240

Ferraz E. Management and diseases of the ornamental fish exported from the Rio Negro basin. In: Val AL, Almeida-Val VM (Eds.). Biology of tropical fishes. Manaus: INPA; 1999. p. 99-111.

Figueroa SN, Nobre CA. Precipitation distribution over Central and Western tropical South America. Climanan 1989; 5(6): 36-45.

Fujimoto RY, Barros ZM, Marinho-Filho AN, Diniz DG, Eiras JC. Parasites of four ornamental fish from the Chumucuí River (Bragança, Pará, Brazil). Rev Bras Parasitol Vet 2013; 22(1): 34-38. http://dx.doi. org/10.1590/S1984-29612013005000015. PMid:23538504

Goldstein RJ. Cichlids of the world. New Jersey: T.F.H. Publications, Inc. Ltd; 1973. 382 p.

Gómez-Laplaza LM, Morgan E. The influence of social rank in the angelfish, Pterophyllum scalare, on locomotor and feeding activities in a novel environment. Lab Anim 2003; 37(2): 108-120. http://dx.doi. org/10.1258/00236770360563741. PMid:12689421

Grutter A, Deveney M, Whittington ID, Lester RJG. The effect of the cleaner fish Labroides dimidiatus on the capsalid monogenean Benedenia lolo parasite of the labrid fish Hemigymnus melapterus. J Fish Biol 2002; 61(5): 1098-1108. http://dx.doi.org/10.1111/j.1095-8649.2002. tb02458.x. 
Kim JH, Hayward CJ, Joh SJ, Heo GJ. Parasitic infections in live freshwater tropical fishes imported to Korea. Dis Aquat Organ 2002; 52(2): 169-173. http://dx.doi.org/10.3354/dao052169. PMid:12542094

Kullander S. Cichlid fishes of the Amazon River drainage of Peru. Stockholm: Swedish Museum of Natural History; 1986. 431 p.

Kullander S, Silfvergrip A. Review of the South American cichlid genus Mesonauta Günther (Teleostei, Cichlidae) with descriptions of two new species. Rev Suisse Zool 1991; 98(2): 407-448.

Lom J, Dykova I. Protozoan Parasites of Fishes. Amsterdam: Elsevier; 1992. 253 p. vol. 26. Developments in Aquaculture and Fisheries Science.

MacMillan JR. Biological factors impinging upon control of external protozoan fish parasites. Annu Rev Fish Dis 1991; 1: 119-131. http:// dx.doi.org/10.1016/0959-8030(91)90026-G.

Moreau M, Coomes OT. Aquarium fish exploitation in western Amazonia: conservation issues in Peru. Environ Conserv 2007; 34(1): 12-22. http://dx.doi.org/10.1017/S0376892907003566.

Olivier K. The ornamental fish market. Rome: FAO/GLOBEFISH Research Programme; 2001. 91 p. vol. 67.

Piazza RS, Laterça ML, Guiraldelli L, Yamashita MM. Parasitic diseases of freshwater ornamental fishes commercialized in florianópolis, Santa Catarina, Brazil. B Inst Pesca 2006; 32(1): 51-57.

Sasal P. Experimental test of the influence of the size of shoals and density of fish on parasite infections. Coral Reefs 2003; 22(3): 241-246. http:// dx.doi.org/10.1007/s00338-003-0313-6.

Schalch SHC, Moraes FR. Distribuição sazonal de parasitos branquiasis em diferentes especies de peixes em pesque-pague do município de Guariba-SP, Brasil. Rev Bras Parasitol Vet 2005; 14(4): 141-146. PMid:16445870.
Silva AEP, Angelis CF, Machado LAT, Waichaman AV. Influência da precipitação na qualidade da água do Rio Purus. Acta Amazon 2008; 38(4): 733-742. http://dx.doi.org/10.1590/S0044-59672008000400017.

Skinner RH. The interrelation of water quality, gill parasites, and gill pathology of some fishes from south Biscayne Bay, Florida. Fish Bull 1982; 80(2): 269-280.

Takemoto RM, Lizama MAP, Guidelli GM, Pavanelli C. Parasitas de peixes de águas continentais. In: Paiva MR, Takemoto RM, Lizama MAP (Org.). Sanidade de Organismos Aquáticos. 1. ed. São Paulo: Editora Varela; 2004. p. 179-197. vol. 1.

Tavares-Dias M, Moraes FR, Martins ML, Kronka SN. Fauna parasitária de peixes oriundos de "pesque-pague" do município de Franca, São Paulo, Brasil. II. Metazoários. Rev Bras Zool 2001; 18(S1): 81-95. http://dx.doi. org/10.1590/S0101-81752001000500006.

Tavares-Dias M, Lemos JR, Martins ML. Parasitic fauna of eight species of ornamental freshwater fish species from the middle Negro River in the Brazilian Amazon Region. Rev Bras Parasitol Vet 2010; 19(2): 103-107. http://dx.doi.org/10.4322/rbpv.01902007. PMid:20624347

Thatcher VE. Amazon fish parasites. Amazoniana 1991; 11(3): 263-572.

Thilakaratne IDSIP, Rajapaksha G, Hewakopara A, Rajapakse RPVJ, Faizal ACM. Parasitic infections in freshwater ornamental fish in Sri Lanka. Dis Aquat Organ 2003; 54(2): 157-162. http://dx.doi. org/10.3354/dao054157. PMid:12747641

Travassos L, Artigas P, Pereira C. Fauna helmintológica dos peixes de água doce do Brasil. Arch Inst Biol 1928; 1: 5-68.

Wedemeyer G. The role of stress in the disease resistance of fishes. In: Snieszko SF (Ed.). A symposium on diseases of fishes and shellfishes. Washington: Am. Fish. Soc.; 1970. p. 30-35. Special Publication no. 5. 


\section{Erratum}

In the article "Parasitic infections in ornamental cichlid fish in the Peruvian Amazon" published in Issue 1, volume 24, 2015, the Brazilian Journal of Veterinary Parasitology, on page 82, which reads:

"Bruno L. Marotta"

Read up:

"Bruno Tadeu Marotta Lima" 